Original Contribution

\title{
ORDER OF MARKET ENTRY AS A SUCCESS FACTOR IN PRODUCT INNOVATIONS
}

\author{
K. Marinov* \\ Department of Marketing and Strategic Planning, University of National and World Economy, \\ Sofia, Bulgaria
}

\begin{abstract}
The purpose of the article is to make a review of the studies dealing with the order of company market entry as a success factor for new products. On the one hand, the interest in the review is driven by the need to develop and launch successful new products and, on the other, the high likelihood for product failure was confirmed by a lot of studies. Furthermore, research in the last years has considered the order of company market entry a factor that determines the market performance of company new products. As a result of the review, a classification is proposed of the studies on the order of company market entry including three areas: consequences of company market entry; pre-entry conditions; characteristics of the economic environment influencing the first two areas. The main conclusion formulated in the article is that, overall, the studies on the order of market entry support the relation between entry timing and company performance with the order of market being a question of matching company resources and capabilities, and environment requirements. The methods of analysis and synthesis as well as induction and deduction are used in the article.
\end{abstract}

Key words: new products, product performance, company resources and capabilities, entry timing, first mover advantage, first movers, early entrants, late entrants

\section{INTRODUCTION}

The need for development and launch of successful new products is related to a number of circumstances, among which are the entry into more and more mature markets and the resulting need to enrich product range in order to meet nuanced needs better; the accelerated product ageing manifested in the relatively shorter product life cycle; in many sectors of the economy, the focus on retaining current consumers, not so much on the influx of new ones because of the lack of such, etc. It is of particular importance that the development of new products is one of the company approaches for organic growth which is paramount in times of crises.

At the same time, the studies are explicit that new product development is related to a significant risk of failure. The high likelihood

\footnotetext{
*Correspondence to: Krasimir Marinov, Assoc. Prof., PhD, Department of Marketing and Strategic Planning, University of National and World Economy, Sofia 1700, Bulgaria,

k_marinov@mail.bg
}

of new product failure together with the growing need for product innovation projects make the research on the circumstances influencing new product performance relevant and important.

Studies show that the order of company market entry is related to the market performance of company new products and that is why it is among their success factors.

The object of research in this article is the development of new products by Bulgarian companies and the subject of research is the order of company market entry as a factor influencing new product performance.

The purpose of the article is to make a review of the studies examining the order of company market entry as a success factor of new products. To achieve this goal, two tasks are set: first, to present the typology of product innovations according to the order of market entry; second, to group the studies on the order of company market entry. 


\section{TYPOLOGY OF PRODUCT}

INNOVATIONS ACCORDING TO THE ORDER OF COMPANY MARKET ENTRY

The three large-scale meta-analytic studies on the success factors of new products published so far - those of Montoya-Weiss and Calantone, of Henard and Szymanski, and of Evanschitzky et al., consider the order of market entry alone or in combination with other success factors an important determinant of product innovation results (1-3).

Most researchers see the time for new product development and market timing as two interrelated but different time aspects of new product development. Most often, studies assume that the two aspects are a source of competitive advantages leading to a bigger market share and greater profitability of the new product. The emphasis on reducing the time for new product development is based on the view that the company that first introduces a product on the market gets the biggest market share and hence has the highest profitability. Therefore, the logic here is that managers must always try to accelerate product development time.

This logic, however, is not undeniable: some empirical studies show that market pioneers perform better than late entrants, whereas other studies state that late entrants perform better than the former. The explanation of this can be the fact that research often focuses on the order of market entry, not on the moment of entry in terms of the window of opportunity for the new product. This way, the sales opportunities offered by the market window of the new product are not grasped. Early entrants may not generate sales since they enter the market when the window is not open yet and followers may not generate sales since they enter the market when the window is already closed.

Langerak et al. define the concept of professional market entry as the company's capability for the right market entry timing (4). This capability is realised by balancing the risks of early entry and of missing an opportunity because of late entry. Boulding and Christen note that consumers build up sustainable positive preferences for new products entering the market at the right moment (5). Often, such products become the standard for a whole product category which
MARINOV K.

influences consumer evaluation of the other products.

Other advantages of professional market entry are the opportunity for a company to take the most attractive position on the market leading to a considerable sales volume as well as the opportunity to generate additional sales due to the consumers that have anchored to it in categories characterised by high costs for supplier change.

Rodríguez-Pinto et al. investigate the way the order of market entry influences the advantages a company can take off its market orientation (6). The authors defend the position that whether for a given new product a company will orient towards the superiority of product quality or greater process speed, depends on the expected order of market entry. The studies published so far give a reason to distinguish three product types according to the order of market entry: first movers, early entrants and late entrants. First mover products have no direct competition but compete with other forms of the product available in the product category as well as with the substituting product categories satisfying the same need. Fast follower products rival with one or several products that are already on the market. This type of products enter the market in the first stage of the product cycle before new product sales have taken off. Late mover products follow the first mover and the early entrants and enter a growth or mature market, i.e. after new product sales have taken off.

The results of the first mover products are that the impact of market orientation on the new product performance is realised only through the product quality. This means that for these companies product advantage is the most important characteristic in terms of sampling and accepting new products. Using market orientation in the development of high quality products can help the companies introducing first mover products to achieve enough market penetration before competitors have reacted. As for early entrants, unlike first movers, they have to develop their innovations quickly. There is very little time for response to prevent first movers from getting access to distribution channels or earning a good reputation among consumers (7). Reducing the time for new product development helps early entrants strengthen their competitive position before the new competition has appeared. Strong market 
orientation can facilitate this kind of companies in accelerating the development of their new products and thus they can increase their chances for success. For these companies, there is a strong relation between product quality and new product success. For late entrants the advantages of market orientation are due to the development of high quality products, not to the reduction of the time a product needs to reach the market. By actively studying market environment and then analysing, disseminating and using this knowledge in decision making, a late entrant can offer a new product with higher quality than the products of early entrants. Such companies cannot profit from product innovation acceleration.

The decisions about company market entry are complicated for they often reflect a change in the strategy, operations, business model, etc. that go along with uncertainty that is beyond the company. Market participants should consider different options in terms of the inherent risk of certain resources they require, of the degree of process control and results from market entry. For instance, there are various options to enter a market (alone or with a partner); what market to enter (a new or an established one, domestic or international); what order of market entry to choose (first or second mover, early or late entrant). The choice of one or another option influences company development, the scale of its operations, its relations with partners, its position in the sector, etc. and they all have an impact on its performance and survival.

Apart from the way of market entry and the circumstances related to it which are key characteristics, the order of market entry is also a significant area of research in marketing and management. Zachary et al. define the order of entry as the time of company emergence in a new or already existing space (e.g. a market, sector or geographic region), compared to rivals, technological development, product life cycle or other specific features of the environment (8). To a great extent, the researchers focused on market entry take into account the concept of the advantage of the first company on a market, although studies focus on the advantages and disadvantages in terms of time: from the first movers and early entrants (e.g. 9) to late entrants (e.g. 10).
MARINOV K.

Following the publication of the founding article in this field by Lieberman and Montgomery in 1988, the view prevailed regarding the importance of the field, but the combination of different circumstances, the challenges of different methodological approaches and conceptual understandings make it difficult to develop a unified theory of the order of market entry (7). Among the most prominent researchers in the field apart from the ones that have already been cited, are Fosfuri, Lanzolla and Suarez; Zachary, Gianiodis, Payne and Markman; Szymanski, Troy and Bharadwaj; Green, Barclay and Ryans; Robinson and Chiang; Bowman and Gatignon, etc. (11, 8, 12-15).

The studies on the order of company market entry can be divided into three groups: consequences of company market entry; preentry conditions; characteristics of the business environment influencing the first two areas. The results concerning each of these groups will be summarised in the next parts of the article.

\section{CONSEQUENCES OF MARKET ENTRY}

The consequences of company market entry are considered as dependent variables (results) of the decisions on the order of market entry, which are considered as independent variables. For instance, a number of studies examine the effect of different strategies of market entry on company performance (e.g. market share, profitability) or product performance (e.g. consumer preferences, brand recall, product diffusion). Therefore, it is possible to distinguish studies at the company level and studies at the product level.

A) Studies at company level. In their early attempt to summarise the major correlation between entry market and company performance, Szymanski et al. carry out a meta-analysis of 16 studies which shows that generally early market entry is in a positive correlation with company market share in the sector (12). As a whole, the subsequent publications support this summarised result, even though the reasons for it vary in the different studies. For instance, Suarez and Lanzolla enumerate three possible explanations for the positive correlation between early market entry and company positive performance: first, the complex of company resources and capabilities gives advantages to early entry; second, there are also mechanisms 
restricting competition which give advantage to the first as well: leadership in technology, a monopolistic access to scarce resources, costs of switching to another competitor, etc.; and third, specific features of the sector and the environment can enhance or diminish the benefits related to market timing (16). Having examined over a hundred empirical publications, Zachary et al. summarise that although other theories and approaches were incorporated, the concept of the first mover advantage remains the major viewpoint used to investigate the relation between market timing and the results obtained at company level (8).

It should be taken into account that although most studies support the relation mentioned above, there are studies that do not confirm it or contain mixed findings. For instance, a question researchers ask is about the conditions under which long-term costs start to outweigh the advantages of long-term demand provided by the strategies for early market entry. In their study, Boulding and Christen find out that the first mover advantage disappears after $12-14$ years on average, except in the cases of mechanisms restricting competition such as reduced consumer ability to learn, big market share of the company, and/or company ownership on patents (5). In a similar study, Dobrev and Gotsopoulos argue that in the early years of an industry, when organisation forms and functional requirements are not fully established, the risk of failure for early entrants is higher compared to early entrants in more mature industries (17). Some scholars investigate more unconventional, for example, non-financial, manifestations of market timing. Robinson and Chiang, for instance, show that the order of market entry has a longstanding effect on the strategies for new product development, particularly on indicators like product innovations intensity, research and development costs, volume of new product sales, share of new product sales, etc. (14). According to this study, generally, early entrants are oriented towards more gradual (not that radical) innovations in their strategies for new product development. The contribution of the cited authors as well as of other scientists is the justification of the relation between environmental uncertainty and certain disadvantages of early market entry.

It can be concluded that at company level, studies on the order of market entry support the
MARINOV K.

relation between market entry timing and company performance as a whole but not unconditionally. In the context of developing a market, for instance, the main challenges to early entrants are mostly of endogenous character, i.e. the question is whether they have the resources and capabilities to develop a market and attract customers. Meanwhile, the challenges to late entrants are more of exogeneous character - how the companies that have already established their positions on the market, including early entrants, will react to this attack.

B) Studies at product level. Generally, studies at the product level also support the view that first movers and early followers win from entering a market first and the arguments in favour are related to consumer preferences. In particular, the companies attracting customers earlier, can influence the way consumers evaluate the different qualities of a product as well as the "ideal" combination of qualities. Furthermore, first movers win from having their products perceived as "standards" in the corresponding product category. Classical examples of this are diapers, nylon, the photocopier, etc. This kind of advantage is different from product level of functioning and quality.

There are scholars like Alpert and Kamins, for instance, who defend the view that consumers have higher long-term preferences for pioneer brands as a result of product's high level of functioning/high quality (18). According to them, consumers associate first movers with the idealised values of originality, innovativeness and reliability. In this sense, first movers are rewarded by consumers for reducing the uncertainty related to a new offer. Other studies at product level follow the approach at company level by relating early entry to the advantages it brings in terms of receiving access to scarce resources, availability of adequate capabilities, and market position. For instance, Dos Santos and Peffers prove that early entrants profit from availing of tangible and intangible opportunities. Examining ATM devices deployment, they find out that early followers enjoy having a bigger market share and better results thanks to acquiring the best locations and thus receiving exclusive access to consumers (19). What is more, early entrants accumulate deeper knowledge of products and markets through the effects of learning. 


\section{MARINOV K.}

Similarly to the studies at company level, the advantages of the early entry of a product on the market are not unambiguous. In a largescale study, Golder and Tellis find out that the average market share of first movers is only $10 \%$ and almost half of these companies fail. In comparison, early followers have a significantly higher average market share (around 28\%) and a considerably smaller share of companies that failed (around 8\%) (20). The conclusion is that followers are more successful than first movers since survival and long-term performance depend on the ability to acquire and use resources and capabilities for large-scale production.

It can be concluded that that early entry products have the advantage to accumulate in time more direct relations with consumers and better knowledge of technology and products, but late entrants have more time to gather information about competitors, suppliers and market trends. In other words, late entrants can choose who to compete with or how to differentiate from early entrant rivals; while first movers are tied to what they have already achieved on the market and are subject to the competitive decisions of late entrants. Pioneer companies are not helpless at all since they can keep moving forward by constantly redefining the market and consumer choice criteria.

\section{PRE-ENTRY CONDITIONS}

Pre-entry conditions have been investigated mainly based on the assumption that there are first mover advantages. There can be distinguished three major groups of pre-entry conditions: strategic intentions and decisionmaking; company resources and capabilities; market and industry conditions. As far as this area of research is concerned, it is possible to distinguish studies at the company level and studies at product level, with the former being focused more on company resources and capabilities and the latter - on factors like strategic intention and decision-making.

A) Studies at the company level. In their research, Robinson and Chiang argue that different company capabilities support different strategies in terms of the order of market entry (14). In particular, the capabilities for research and development are considered by them a prerequisite for early market entry; production capabilities are a pre-condition for a company to be an early follower, and marketing capabilities are a pre-condition for the late market entry. Hawk et al. emphasize another time aspect and show that companies capable of working faster, can wait longer before entering an emerging market without significant negative consequences (21).

It can be summarised that the cited studies make a connection between market entry and company capabilities, which means that market entry timing can be viewed as a function of the dynamic company capabilities.

In addition to the company advantage of available resources, research also reveals the importance of the environment and strategic intentions - considered together or individually - for market timing. For instance, Folta and O'Brien prove that industry characteristics like growth opportunities and uncertainty influence market entry timing (22). They find out that companies have the possibility to choose whether to postpone entry timing or to enter and grow together with the market. In conditions of uncertainty, the possibility to postpone does not stimulate market entry, although considerable growth potential can outweigh entry postponement even at high levels of uncertainty.

Market capabilities and attractiveness are important determinants on both domestic foreign markets. For instance, studying the entry of big American companies into China, Gaba et al. establish that bigger companies which are more experienced internationally often enter a market before the rest of the companies (23). Similarly, Tan and Vertinsky show that the likelihood to make direct foreign investment is higher for companies with experience on a given market or in international operations (24).

B) Studies at product level. Similarly to the studies at company level, the factors influencing entry market at product level include resources and capabilities, intentions, ways of entry, specific features of the given industry. In a number of cases, the authors use game theory to investigate the order of market entry when these decisions are based on competitor behaviour and the strength of competing products. Krider and Weinberg, for example, study the film market in the USA and the advantages of releasing a film earlier having in mind the potential of the rival film (25). Similarly, Ethiraj and Zhu prove that market entry timing of imitating companies is a consequence of information asymmetry in 
which the lack of information about the product of the pioneer company makes it more profitable for the follower company to delay its entry (26). A contribution of the cited studies is the finding that market entry decisions are made in a context of a dynamic company competition.

A specific aspect of the research on market entry at product level is the development of company mix by adding new products. Using the idea of cannibalisation and the cases when companies restrain from being the first on the market, Wilson and Norton ask the question about the most appropriate moment for introduction of a product extending the product line (27). They conclude that on the one hand, line extension reduces the margin of profit per unit because it eats part of the existing products sales, but on the other, it can contribute to market expansion and sales boost. Therefore, it is often better to introduce a line extension earlier in a product life cycle or not introduce it at all. Investigating the balance between benefits (availing of company capabilities) and disadvantages (competitors' reaction), Joshi et al. conclude that even given the negative effect, it is often recommendable to enter a new market (28). This logic, however, is not indisputable since as it was mentioned above, the results from market entry depend on a variety of factors, including the degree of market penetration.

It can, therefore, be summarised that the studies on market entry at company and product level are relevant, with both types showing that endogenous (e.g. resources and capabilities, strategic intentions) as well as exogenous (e.g. specific features of the market, industry and country) conditions have key importance for the explanation of market entry timing. Although a lot of studies imply that being the first to enter a market is a desired goal, this assumption is not indisputable. Rather, it can be concluded that the advantages of a given market entry (early or late) show that there is a deep correspondence between company capabilities (its resources and capabilities) and environmental requirements (the situation with the product and its market) that in turn vary significantly in time and space.

\section{CHARACTERISTICS OF BUSINESS ENVIRONMENT}

The characteristics of business environment are the third area of research. They have impact on the relations between market entry pre-conditions and market entry consequences.
In their study, Zachary et al. establish that in over half of the studies on market entry timing, there is an influence of the environment (8). These influences can be divided into two groups.

\section{A) Relations between the order of market entry and the consequences of market entry.} These influences are based on a wide range of circumstances, including those related to product features (product mix width, synergies for the consumer, imitation of the product by competitors); company characteristics (company resources and capabilities, duration of product development compared to competitors, marketing and communication costs, strategic orientation); specific features of the industry (market uncertainty, rate of change in the industry, level of competition in the industry).

A lot of the relations between the order of market entry and the consequences of market entry refer to features or strategies of the product or of the brand. For instance, in a study of 75 cases of product line extension for 34 brands of cigarettes, Reddy et al. find out that the power of the extending brand combined with early market entry, company size and company marketing competences is in a positive correlation with the line extension success (29).

Company characteristics (e.g. size, structure, etc.) are common features of the environment with a lot of research being based on the resource-based theory. The resources enhancing the advantages of the first mover or of the early entrants are patent protection and knowledge-based competences.

Marketing capabilities as well as the capabilities in the field of research and development are among the variables with the greatest impact on the relation between the order of market entry and market entry consequences. For late entrants, the resources and capabilities influencing the same relation are as well as company innovation capabilities (30).

The conditions in the industry and on the market matter as well. For instance, in a study of the order of the market entry of four products in sixteen countries, Ganesh et al. find out that products enter faster in countries that are culturally and economically similar to the first country in which the product was 
introduced (31). The same study shows that product entry is accelerated when there is a longer period of time between the product introduction in the first country and its introduction in the subsequent countries. In the study cited above, Krider and Wienberg find out that for the companies facing highly competitive offers, it is better to delay their market entry.

It can be summarised that the relation between the order of market entry and the consequences of market entry cannot be easily explained with simple and direct correlations. That is why studies include increasingly bigger and more varied factors that can have impact on the consequences of market entry.

B) Relations between market entry preconditions and the order of market entry. Generally, the research on these relations is focused on one or several factors influencing the relationship between a strategic intention or capabilities in the industry and the opportunity to enter first or delay entry. For instance, Bayus et al. prove that the companies able to predict the market better and have better abilities to use their resources effectively, gain an advantage when they are the first to enter a market (32). In the previously cited study of Hawk et al., the authors come to the conclusion that the companies working faster can wait longer before entering the market, shortening the period of greatest uncertainty and avoiding the risk of entering a market that may be blocked by a competitor (21).

Therefore, the studies cited so far show that there is a variety of factors at company or product level that stimulate or discourage companies to be the first to enter a market. Nevertheless, product features and profit potential above market average influence these factors as well, thus confirming the complex and multi-faceted nature of the decisions on the order of market entry.

\section{CONCLUSION}

The choice of the right moment for market entry is a key company competence. In the research on the order of market entry, prevails the view that the first mover to a market gains an important advantage. Overall, the studies on the order of market entry support the relation between market entry timing and company performance. Early entrants have the opportunity to build customer relations and gain knowledge about products and technology, whereas late entrants have the opportunity to obtain information about competitors and suppliers.

Studies show that being the first on a market is not always the option preferred by companies. Rather, the order of market entry is a question of matching company resources and capabilities to environment requirements.

\section{REFERENCES}

1. Montoya-Weiss, M. M., \& Calantone, R., Determinants of new product performance: A review and meta-analysis. Journal of Product Innovation Management, 11(5), 397-417, 1994.

2. Henard, D. H., \& Szymanski, D. M., Why some new products are more successful than others? Journal of Marketing Research, 38(3), 362-375, 2001.

3. Evanschitzky, H., Eisend, M., Calantone, R. J., \& Jiang, Y., Success factors of product innovation: An updated metaanalysis. Journal of Product Innovation Management, 29(S1), 21-37, 2012.

4. Langerak, F., Hultink, E. J., \& Griffin, A., Exploring mediating and moderating influences on the links among cycle time, proficiency in entry timing, and new product profitability. Journal of Product Innovation Management, 25(4), 370-385, 2008.

5. Boulding, W., \& Christen, M., Sustainable pioneering advantage? Profit implications of market entry order. Marketing Science, 22(3), 371-392, 2003.

6. Rodríguez-Pinto, J., P. Carbonell, and A. I. Rodríguez-Escudero, Speed or quality? How the order of market entry influences the relationshp between market orientation and new product performance. International Journal of Research in Marketing 28: 145-54, 2011.

7. Lieberman, M. B., \& Montgomery, D. B., First-mover advantages. Strategic Management Journal, 9(S1), 41-58, 1988.

8. Zachary, M. A., Gianiodis, P. T., Payne, G. T., \& Markman, G. D., Entry timing: Enduring lessons and future directions. Journal of Management, 41(5), 1388-1415, 2015.

9. Kerin, R. A., Varadarajan, P. R., \& Peterson, R. A., First-mover advantage: A synthesis, conceptual framework, and research propositions. Journal of Marketing, 33-52, 1992.

10. Shankar, V., Carpenter, G. S., \& Krishnamurthi, L., Late mover advantage: 
How innovative late entrants outsell pioneers. Journal of Marketing Research, 35:54-70, 1998.

11. Fosfuri, A., Lanzolla, G., \& Suarez, F. F., Entry-timing strategies: The road ahead. Long Range Planning, 46(4-5), 300-311, 2013.

12. Szymanski, D. M., Troy, L. C., \& Bharadwaj, S. G., Order of entry and business performance: An empirical synthesis and reexamination. Journal of Marketing, 17-33, 1995.

13. Green, D. H., Barclay, D. W., \& Ryans, A. B., Entry strategy and long-term performance: Conceptualization and empirical examination. Journal of Marketing, 1-16, 1995.

14. Robinson, W. T. \& Chiang, J., Product development strategies for established market pioneers, early followers, and late entrants. Strategic Management Journal, 23(9), 855-866, 2002.

15. Bowman, D., \& Gatignon, H., Determinants of competitor response time to a new product introduction. Journal of Marketing Research, 42-53, 1995.

16. Suarez, F. F., \& Lanzolla, G., The role of environmental dynamics in building a first mover advantage theory. Academy of Management Review,32(2), 377-392, 2007.

17. Dobrev, S. D., \& Gotsopoulos, A., Legitimacy vacuum, structural imprinting, and the first mover disadvantage. Academy of Management Journal, 53(5), 1153-1174, 2010.

18. Alpert, F. H., \& Kamins, M. A., An empirical investigation of consumer memory, attitude, and perceptions toward pioneer and follower brands. Journal of Marketing, 34-45, 1995.

19. Dos Santos, B. L., \& Peffers, K., Rewards to investors in innovative information technology applications: First movers and early followers in ATMs. Organization Science, 6(3), 241-259, 1995.

20. Golder, P. N., \& Tellis, G. J., Pioneer advantage: Marketing logic or marketing legend?. Journal of Marketing Research, 158-170, 1993.

21. Hawk, A., Pacheco-De-Almeida, G., \& Yeung, B., Fast-mover advantages: Speed capabilities and entry into the emerging submarket of Atlantic basin
LNG. Strategic

MARINOV K.

Journal, 34(13), 1531-1550, 2013.

22. Folta, T. B., and O'Brien, J. P., Entry in the presence of dueling options. Strategic Management Journal, 25(2), 121-138, 2004.

23. Gaba, V., Pan, Y., \& Ungson, G. R., Timing of entry in international market: An empirical study of US Fortune 500 firms in China. Journal of International Business Studies, 33(1), 39-55, 2002.

24. Tan, B., \& Vertinsky, I., Foreign direct investment by Japanese electronics firms in the United States and Canada: Modelling the timing of entry. Journal of International Business Studies, 27(4), 655681, 1996.

25. Krider, R. E., \& Weinberg, C. B., Competitive dynamics and the introduction of new products: The motion picture timing game. Journal of Marketing Research, 1-15, 1998.

26. Ethiraj, S. K., \& Zhu, D. H., Performance effects of imitative entry. Strategic Management Journal,29(8), 797-817, 2008.

27. Wilson, L. O., \& Norton, J. A., Optimal entry timing for a product line extension. Marketing Science, 8(1), 1-17, 1989.

28. Joshi, Y. V., Reibstein, D. J., \& Zhang, Z. J., Optimal entry timing in markets with social influence. Management Science, 55(6), 926-939, 2009.

29. Reddy, S. K., Holak, S. L., \& Bhat, S., To extend or not to extend: Success determinants of line extensions. Journal of Marketing Research, 243-262, 1994.

30. Shamsie, J., Phelps, C., \& Kuperman, J., Better late than never: A study of late entrants in household electrical equipment. Strategic Management Journal, 25(1), 69-84, 2004.

31. Ganesh, J., Kumar, V., \& Subramaniam, V., Learning effect in multinational diffusion of consumer durables: An exploratory investigation. Journal of the Academy of Marketing Science, 25(3), 214-228, 1997.

32. Bayus, B. L., Jain, S., \& Rao, A. G., Too little, too early: Introduction timing and new product performance in the personal digital assistant industry. Journal of Marketing Research, 50-63, 1997. 